\title{
Impact of Dividend Policy on Financial Performance - A Study
}

\author{
Pradip Kumar Das $P h D$ \\ Associate Professor \\ Jagannath Kishore College, Purulia (West Bengal) \\ Affiliation under Sidho-Kanho-Birsha University, Purulia, India \\ E-mail.: pradip57.prl@rediffmail.com
}

\begin{abstract}
This study is an attempt to evaluate the impact of dividend policy on financial performance of selected companies registered in Bombay Stock Exchange. The study based on correlation matrix and panel regression model shows that the selected companies do not follow consistent pattern of dividend payments and the association between price earnings ratio and dividend payout ratio is low positive. However, there is strong association between return on assets and return on equity. Hausman Test reveals that random affect model is appropriate thereby indicating that performance of selected companies have momentous impact on dividend policy. Divided policy is still contemplated as one of the complicated areas in corporate finance. The findings from this study are worthwhile to be welcomed into account by the board of managers of companies to demonstrate dividend policy for the companies.
\end{abstract}

\section{Keywords: Dividend policy, Performance, Earnings per Share, Price Earnings Ratio, Return on Assets, Return on Equity.}

\section{Introduction}

Corporate dividend policy decision not only emphasizes important demonstration about the possibilities of business growth but also influences other business decisions like investment and finance. Dividend policy shows the opportunity for investment, future expansion and growth (Afza \& Mirza,20II). It revolves around decision making between distribution of current return and reinvestment of the same for future return (Pandey\&Ashvini,20I6;Kouser,Luqman,Yaseen and Azeem,2015).Dividend policy is a corporate finance decision on transfer of value in the form of dividend from an organization to its shareholders out of the profits available for a prescribed period of time(Okafori and Mgbame,20I I).Pragmatic management of corporate pertains to earnings distribution in the form of dividend to shareholders over time (Ajanthan,2013). Design of dividend policy details the segment of company's earnings as return on shareholders' investment in the form of cash dividend or stock dividend (Abdul and Muhibudeen,20I5). Pertinence of dividend policy in the discourse of corporate performance reflects bifurcation yet to be resolved (Abdul and Muhibudeen,2015).

\section{Literature Review}

Kolawole, E.et al.(2018)observed in their study favorable or positive impact of dividend payout and retention ratios on EPS in the Nigerian oil and gas firms. Kanwal, M. \& Hameed, S. (2017) found efficacious influence of dividend payout on financial performance of firm. Thirumagal, P.G. and Vasantha, S. (2018) perceived pessimistic or negative impact of dividend payout on shareholders' wealth for majority of the Indian industries. Significant difference was found in share price between pre and post dividend announcements. Velmurugan (2015) noticed association of dividend declaration in Indian fertilizer industry with previous year's dividend, current year's depreciation and current year's profit after tax, current year's sales and previous year's cash flow. Labhane \& Mahakud (2016) distinguished that investment opportunity, financial leverage, company size, business risk, firm life cycle, profitability, tax and liquidity are major determinants of dividend policy for Indian companies. Das (20I7) confirmed that leverage not size is an important determinant of dividend of Bombay Stock Exchange companies in India. Abiola (20I4) observed that among other things both current and past year's profits fix dividend policy of firm indicating that performance of firm in terms of profitability is vital in the pattern of dividend policy. Pandey \& Ashvini (2016) propounded that dividend policy of firm is governed by factors including debt-equity ratio, earnings, corporate tax, earnings per share, and firms' size. Kurawa \& Ishaku(20I4)recognized corporate governance as a determinant of dividend policy. Sakinc \& Gungor(2015)acknowledged ownership structure as a determinant of dividend policy of firms. Yusof and Ismail, (20I6) suggested that before deciding payment of dividend, the companies board should consider profit, debts, investments and also the size of shareholders. Maladjian and El Khoury (2014) studied the effects of size, dividend payments, debt, profitability, liquidity, growth and firm's risk on dividend payout ratios of banks listed on Beirut Stock Market in Lebanese for the period 
from 2005 to $201 \mathrm{I}$ and observed efficacious relationship between size, risk and lag dividends, and observed pessimistic relationship between profitability and opportunity growth with dividend payout policy of firms. Chawla and Chadha (2014)and Mbuvi(2015)empirically studied the effect of dividend announcement, dividend payout, tax incentives and excess cash flows on shareholders wealth in Nairobi Securities Market and revealed positive influence of dividend announcement, dividend payouts, tax incentives and free cash flows on shareholders' wealth. Yegon, C., Cheruiyot, J.\&Sang,J.(20I4)found pragmatic relationships between dividend policies of organizations and firm's profitability, between dividend policy and investments, and between dividend policy and EPS. Masum, A. (20I4) watched in the study with the help of Panel data approach positive correlation between dividend and stock price considering EPS, ROE, Retention Ratio; while dividend yield and profit after tax have negative relation with stock prices. Khan, et al (2016) showed negative relation of dividend payout ratio and leverage with the return on equity on the stock listed in PSE; while positive relation between ROA, dividend policy, and growth in sales. Labhane, N.B. \& Mahakud Jitendra (2016) advocated positive impact of dividend policy on profitability and EPS.

\section{Purpose Behind the Study}

Dividend policy is a controversial subject to many researchers. A universe hypothesis that dividend plays a considerable role has been examined by many empirical studies and behavioral surveys. A strong perception as to the passion behind dividend yields opportunity to more study. Literature suggests dividend provides additional worth to company in the eyes of investors; but it is uncertain what financial factors management exercises to support their reasoning behind initiating dividend policy. The study searches potential factors influencing dividend decision of a large sample of dividend paying companies.

\section{Objective}

The prime objectives of the study are:

- To explore how dividend policy of the selected companies influence their profitability;

- To check how dividend policy of companies and their profitability is associated;

- To analyze the impact of dividend policy on companies ROE;

- To evaluate the impact of dividend policy on companies ROA.

\section{Methodology}

The study in essence rests on secondary data. The researcher, being an external analyst, has to depend substantially on current literature available in the form of books, journals, articles, research studies, official websites, etc. Editing, classification and tabulation of data assembled from these sources have been accomplished as per necessities of the study. Different statistical techniques and tools have also been applied for the purpose of the analysis. Calculations have been done approximately. Correlation Matrix and Panel Regression Model (Fixed Effect and Random Effect) are used to accomplish the objectives of the study. Haussmann Test has been used for the hypothesis. DPR, EPS and PER are used as proxy variables for dividend policy. ROA and ROE are applied to proxy for firm's performance. This paper analyzes the dividend policy of reputed fifty(50)BSE registered Indian companies comprising the group of cement industry, pharmaceutical industry, information technology industry, iron and steel industry during the study period from 2012-2013 to 2018-2019.The companies were selected on the basis of market capitalization obtained from the official website of BSE. Moreover, ratios have been calculated from the data published by the companies in their annual reports.

\section{Results and Discussions}

With a view to attaining the results and the conclusions drawn there from for the study, the methods administered are Correlation Matrix and Panel Regression Model. Performance indicators of dividend policy and profitability are estimated by the following ratios (Table.I).

Table I. Measuring Dividend Policy and Performance (i.e. Profitability)

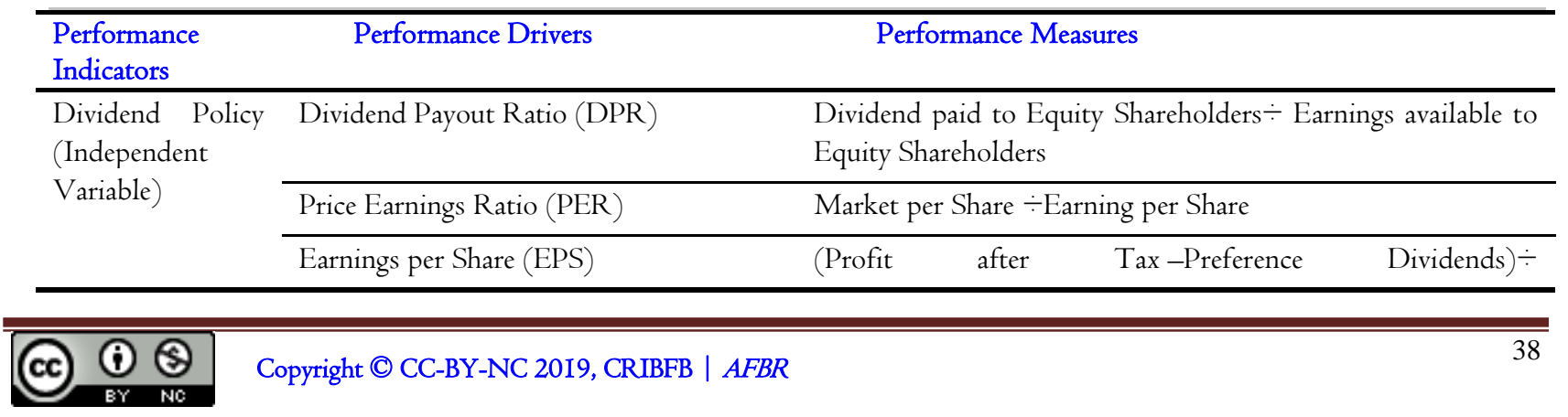




\begin{tabular}{lll}
\hline & & Number of Shares held by Equity Shareholders \\
\hline $\begin{array}{l}\text { Profitability } \\
\text { (Dependent } \\
\text { Variable) }\end{array}$ & Return on Assets (ROA) & Profit after Tax $\div$ Total Assets \\
\cline { 2 - 3 } & Return on Equity (ROE) & $\begin{array}{l}\text { (Profit after Tax - Preference Dividend) } \div \text { Shareholders' } \\
\text { Equity }\end{array}$ \\
\hline
\end{tabular}

\section{I Use of Correlation Matrix}

Correlation Matrix has been used to demonstrate the strength of relationship within the independent variables and between the dependent variables and independent variables. It helps in finding out the pair of variables having the highest correlation.

Table 2. Correlation Matrix

\begin{tabular}{lllll}
\hline \multirow{2}{*}{ DPR } & & DPR & EPS & PER \\
\hline & Pearson Correlation & I & -0.128 & .285 \\
\cline { 2 - 5 } & Sig.(2-tailed) & & .380 & .048 \\
\hline \multirow{2}{*}{ EPS } & $\mathrm{N}$ & 52 & 52 & 52 \\
\hline & Pearson Correlation & -0.128 & $\mathrm{I}$ & .067 \\
\cline { 2 - 5 } & Sig.(2-tailed) & .380 & & .650 \\
\hline PER & $\mathrm{N}$ & 52 & 52 & 52 \\
\hline & Pearson Correlation & .285 & .067 & $\mathrm{I}$ \\
\cline { 2 - 5 } & Sig.(2-tailed) & .048 & .650 & \\
\hline
\end{tabular}

Note- Correlation significant at 0.05 level

Interpretation (I): Table-2 evidences that values of coefficient between the independent variables DPR-EPS, DPR-PER and PER-EPS are -0.128, 0.285 and 0.650 respectively; each value is less than 0.80 . The result demonstrates that there is no multicolinearity existence among the independent variables. However, correlation coefficient between the dependent variables e.g. ROA and ROE is significantly high at 0.915 .

\subsection{Use of Panel Regression Model}

Regression Model is employed to establish the fact that how the particular value of dependent variable changes with any change in one of the independent variables keeping other independent variables constant. Panel Regression Model has been applied in administering multidimensional analysis over a period of time. Two methods are available for panel regression:(I) Fixed Effect Model and(2) Random Effect Model.

(I) Fixed Effect Model: With the assumption that properties of certain variables do not vary across time and may or may not be correlated with the individual dependent variables, it is tested to establish that whether fixed effects or random effects are necessary to upgrade the model. It can be dissected adopting Hausman Test.

(2) Random Effect Model: In this model, parameters are random variables and have similarity with hierarchy liner model. It is used to examine panel data with the assumption of no fixed effects.

\section{Results and Discussions: Model. I: (ROA c DPR PER EPS)}

\section{I Interpretation (2): $\mu \mathrm{OI}$}

There is no significant impact of DPR, PER and EPS on ROA across the panel.

The model with random effect is evaluated and then Hausman Test is exercised to ratiocinate about the method to be used for testing the hypothesis. If prob. value of Hausman Test is less than 0.05 , null hypothesis is rejected indicating appropriateness of the Fixed Effect Model for the study. If null hypothesis is accepted, it is suitable to use Random Effect Model. As prob. value 
(O.I I3) is higher than 0.05, null hypothesis is accepted extrapolating that Fixed Effect Regression model is inappropriate, rather, Random Effect Model is appropriate to use (Table-3).

Table 3. Correlation Random Effects (HausmanTest)

\begin{tabular}{cccc}
\hline & Test Cross Section Random Effects & & \\
\hline Test Summary & Chi-Sq. Statistic & Chi-Sq. d.f. & Prob. \\
\hline Cross Section Random & 5.986 & 3 & 0.113 \\
\hline
\end{tabular}

Table-3.I. Cross Section Random Effects Test Comparison

\begin{tabular}{ccccc}
\hline Variable & Fixed & Random & Var (Diff.) & Prob. \\
\hline DPR & 2.327 & 2.281 & 0.386 & 0.940 \\
\hline PER & 0.225 & 0.178 & 0.009 & 0.630 \\
\hline EPS & 0.084 & 0.097 & 0.001 & Prob. \\
\hline Variable & & & 0.472 \\
\hline C & Coefficient & Std. Error & t-Statistic & 0.003 \\
\hline DPR & II.548 & 3.527 & 0.275 & 0.397 \\
\hline PER & 2.327 & 2.711 & 0.859 & 0.194 \\
\hline EPS & 0.225 & 0.170 & 2.443 & 0.019 \\
\hline
\end{tabular}

Table-3.2. Effects Specification

\begin{tabular}{cccc}
\hline & \multicolumn{1}{c}{ Cross Section Fixed (Dummy Variables) } & Mean Dependent Variable & I9.466 \\
\hline R-Squared & 0.836 & S.D. Dependent Variable & $7.3 \mathrm{I} 8$ \\
\hline Adjusted R-Squared & 0.783 & Akaike Info Criterion & $5.5 \mathrm{I} 4$ \\
\hline S.E. of Regression & $3.4 \mathrm{I}$ & Schwarz Criterion & $6.0 \mathrm{II}$ \\
\hline Sum Squared Resid. & $43 \mathrm{I} .635$ & Hannan Quinn Criterion & 5.703 \\
\hline Log Likelihood & $-\mathrm{I} 24.836$ & Durbin Watson Statistic & $2.3 \mathrm{I5}$ \\
\hline F Statistic & $\mathrm{I} 5.658$ & & \\
\hline Prob.(F-Statistic) & 0.000 & &
\end{tabular}

Other prerequisite conditions also support the model and its result. Probability value of the model being less than 0.05 (0.0000) suggests that inference drawn from the model is correct and the result justified. This also recommends that there is no potency of Type I and Type II errors. R-Square value is 0.83 prescribing that variation in the dependent variable is explained by the independent variable with a percentage value of $83 \%$ and the rest $17 \%$ may be due to the appearance of other factors having indeterminate behavior and approach. Durbin-Watson(D-W) statistics deal with the problem of autocorrelation and stationary alike. D-W statistic value is between 2 and 3 (considered acceptable under the lenient approach). Hence, there is no problem of autocorrelation and adaptability in the model(Table-4).

Table-4. Random Effect Model

\begin{tabular}{ccccc}
\hline Variable & Coefficient & Std. Error & t-Statistic & Prob. \\
\hline C & II.428 & 3.204 & 3.568 & $0.00 \mathrm{I}$ \\
\hline DPR & 2.327 & 2.639 & 0.865 & 0.392 \\
\hline
\end{tabular}




\begin{tabular}{ccccc}
\hline PER & 0.225 & 0.139 & 1.278 & 0.208 \\
\hline EPS & 0.084 & 0.029 & 3.328 & 0.002 \\
\hline
\end{tabular}

Table-4.I. Effects Specification

\begin{tabular}{ccc}
\hline & S.D. & Rho \\
\hline Cross Section Random & 4.753 & 0.659 \\
\hline Idiosyncratic Random & 3.416 & $0.34 \mathrm{I}$ \\
\hline
\end{tabular}

Table-4.2. Weighted Statistics

\begin{tabular}{cccc}
\hline R-Squared & 0.186 & Mean Dependent Variable & 5.956 \\
\hline Adjusted R-Squared & 0.133 & S.D. Dependent Variable & 3.785 \\
\hline S.E. of Regression & 3.525 & Sum Squared Resid. & 571.450 \\
\hline F-Statistic & 3.500 & Durban Watson Statistics & I.632 \\
\hline Prob.(F-Statistic) & 0.023 & & \\
\hline
\end{tabular}

Table-4.3. Unweighted Statistics

\begin{tabular}{cclc}
\hline R-Squared & 0.287 & Mean Dependent Variable & I9.465 \\
\hline Sum-Squared Resid. & I87I.364 & Durban Watson Statistics & 0.564 \\
\hline
\end{tabular}

\section{Results and Discussions: Model. II (ROE c DPR PER EPS)}

\section{I Interpretation (3): $\mu 02$}

There is no significant impact of PER, PER and EPS on ROA across the panel.

Prob. value of Hausman Test (0.488) is greater than 0.05. Thus, null hypothesis is accepted indicating significant result. It can be inferred that Fixed Effect Regression Model is inappropriate and Random Effect Model is appropriate to use(Table-5).

Table-5. Correlated Random Effects(HausmanTest)

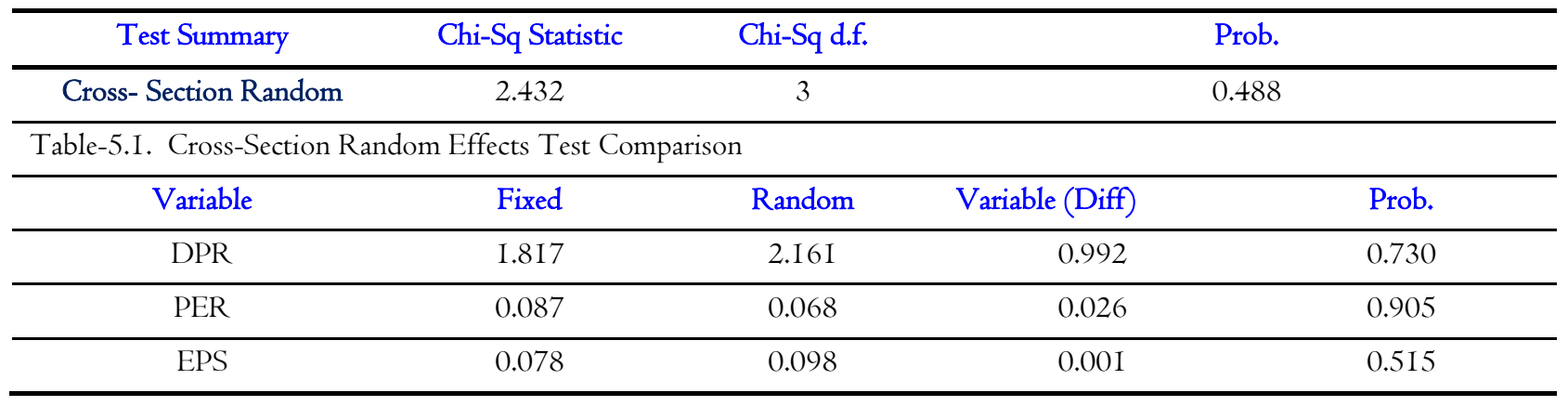

Table-5.2. Cross-Section Random Effects Test Equation

\begin{tabular}{ccccc}
\hline Variable & Coefficient & Std. Error & t-Statistic & Prob. \\
\hline C & 22.665 & 6.550 & $3.46 \mathrm{I}$ & 0.002 \\
\hline DPR & $1.8 \mathrm{I} 7$ & 5.033 & $0.36 \mathrm{I}$ & $0.72 \mathrm{I}$ \\
\hline
\end{tabular}




\begin{tabular}{ccccc}
\hline PER & 0.087 & $0.3 \mathrm{I} 3$ & 0.275 & 0.785 \\
\hline EPS & 0.078 & 0.064 & 1.224 & 0.30 \\
\hline
\end{tabular}

Table-5.3. Effects Specification

Cross-Section Fixed (Dummy Variable)

\begin{tabular}{cccc}
\hline R-Squared & 0.80I & Mean Dependent Variable & 28.456 \\
\hline Adjusted R-Squared & 0.735 & S.D. Dependent Variable & I2.35I \\
\hline S.E. of Regression & 6.343 & Akaike Info Criterion & 6.752 \\
\hline Sum-Squared Resid & I 490.338 & Schwarz Criterion & $7.249 \mathrm{I}$ \\
\hline Log Likelihood & $-\mathrm{I} 56.797$ & Humann-Quinn Criterion & 6.940 \\
\hline F-Statistic & I2.40 & Durbin-Watson Statistic & 2.45 \\
\hline Prob. (F-Statistic) & 0.000 & & \\
\hline
\end{tabular}

Requisite conditions support the use of Random Effect Model and its result. Probability value of the model being less than 0.05 (0.0000) suggests that the inference drawn from the model is correct and the result is justified. It indicates also chances of Type I and Type II errors. R-Square value is 0.80 prescribing that variation in the dependent variable is demonstrated by the independent variable with a percentage value of $80 \%$ and the rest $20 \%$ may be due to presence of other factors having uncertain behavior and movement. D-W. statistics deal with the problem of auto correlation and adaptability alike. D-W. statistics value varies between 2 and 3 (considered acceptable under the lenient approach) signifying no problem of auto correction and adaptability in the model (Table-6).

Table-6. Random Effect Model

\begin{tabular}{lllll}
\hline \multicolumn{1}{c}{ Variable } & \multicolumn{1}{c}{ Coefficient } & \multicolumn{1}{c}{ Std. Error } & t-Statistic & Prob. \\
\hline $\mathrm{C}$ & $2 \mathrm{I} .730$ & 6.442 & $3.37 \mathrm{I}$ & 0.002 \\
\hline $\mathrm{DPR}$ & $2.16 \mathrm{I}$ & 4.935 & 0.435 & 0.664 \\
\hline PER & 0.065 & $0.27 \mathrm{I}$ & 0.245 & 0.805 \\
\hline EPS & 0.095 & 0.055 & $\mathrm{I} .740$ & 0.089 \\
\hline
\end{tabular}

Table-6.I. Effects Specification

\begin{tabular}{lll}
\hline & S.D. & Rho. \\
\hline Cross-Section Random & I0.495 & 0.733 \\
\hline Idiosyncratic Random & 6.345 & 0.268 \\
\hline
\end{tabular}

Table-6.2. Weighted Statistics

\begin{tabular}{llll}
\hline R-Squared & 0.065 & Mean Dependent Variable & 7.425 \\
\hline Adjusted R-Squared & 0.004 & S.D. Dependent Variable & 6.322 \\
\hline S.E. of Regression & 6.304 & Sum-Squared Resid. & I828.720 \\
\hline F-Statistic & 1.084 & Durbin-Watson Statistic & I.915 \\
\hline Prob.(F-Statistic) & 0.000 & & \\
\hline
\end{tabular}


Table-6.3. Unweighted Statistics

\begin{tabular}{llll}
\hline R-Squared & 0.144 & Mean Dependent Variable & 28.453 \\
\hline Sum-Squared Resid. & 6386.842 & Durbin-Watson Statistic & 0.614 \\
\hline
\end{tabular}

\section{Conclusion}

Different dividend ratios selected for the study depicts that sample companies do not have any consistent pattern of dividend payment and trend is skewed in character. Correlation Matrix also exhibits a very low positive association between PER and DPR at 5\% level of significance. Similarly, association between ROA-EPS and ROE-EPS is low positive and significant at I\%. However, there is strong positive association between ROE-ROA at I\% level of significance. Results of both the two regression models exercised in this study are expressive thereby demonstrating suitability of the Random Effect Regression Model. It can be deduced that performance of the selected companies has considerable impact on dividend policy.

\section{I0. Implication of The Study}

Dividend policy and its benchmark of disbursement is a key concern in finance. The study is rejuvenating for managers fascinated in profit planning and investment and will also accommodate the researchers to build more perception on dividend policy which is still an intricate subject in corporate finance. However, this study is a venture to build germane dividend policy model in future.

\section{Research Comment}

Despite pros and cons to dividend policy, the analysis appears to designate that income through dividend is a seductive determinant to investors both for the confirmation of return as well as the management claims. Dividend policy is under management deliberation. A trade-off exists between management's decision as to the implementation and extent of the payout in dividend policy vs. reinvestment. Although there is compact information about dividend policy making process, decisions do not appear to be made delicately. Factors like tax, external financing costs, transaction costs, earnings stability, liquidity position, investment decision, etc. also play decisive role in management's dividend policy.

\section{I2. Future Research}

Further research can be persuaded to establish the cognition of dividend policy and its execution on market-based strategy. Data for several periods can also be exercised for distinguishing payout variation over time and the level of materiality for each determinant. Insertion of more variables like float, PE ratio projections, operating margins, DE ratio, and others may also yield expressive result. The present analysis may be lengthened to study the impact of ownership distinctiveness in case of other developing resources for future research. Impact of board structure on dividend policy is a beguiling effort to research. This is waiting for future research.

\section{Acknowledgement}

The paper is devoted to ALMIGHTY GOD who always shows HIS BLESSINGS in all walks of my life.

\section{References}

Abdul, A. \& Muhibudeen, L.(20I5).Relationship between dividend payout and firms' performance: evaluation of dividend policy of Oando Plc. International Journal of Contemporary Applied Sciences, 2(6),56-7I.

Abdul, A., \& Muhibudeen, L.(2015).Relationship between dividend payout and firms' performance: evaluation of dividend policy of Oando Plc. International Journal of Contemporary Applied Sciences,2(6),56-7I.

Abiola, J.O. (2014).Measuring and Analyzing the Effects of Dividend Policy in Banking Profits and Growth. Journal of Policy and Development Studies, 9(I),I67-I78.

Afza, T., \& Mirza, H.H.(20II).Do mature companies pay more dividends? evidence from Pakistani stock market. Mediterranean Journal of Social Sciences, 2(2),I52-I6I.

Ajanthan, A.(2013).The relationship between dividend payout and firm profitability: a study of listed hotels and restaurant companies in Sri Lanka, International Journal of Scientific and Research Publications.3(6),I-6. 
Chawla, P. K. \& Chadha, N.(2014).A comparative analysis of dividend payout trend of Indian Telecom and steel industries. Shiv Shakti International Journal of Interdisciplinary and Academic Research,3(I),58-73.

Kanwal, M. \& Hameed, S.(2017). The relationship between dividend payout and firm financial performance, Research in Business and Management,4(I).

Khan, M.N., Nadeem, B., Islam, F., Salman, M. and Gill, H.M.I.S.(20I6).Impact of dividend policy on firm performance: an empirical evidence from Pakistan stock exchange, American Journal of Economics, Finance and Management,2(4), 28-34.

Kolawole, E., Sadiq, M.S., \& Lucky, O.(2018).Effect of dividend policy on the performance of listed oil and gas firms in Nigeria, International Journal of Scientific and Research Publications, 8(6).

Kouser, R., Luqman, R., Yaseen, A., \& Azeem, M.(2015).Dividend payout policy and financial crisis: evidence from the Life Cycle Theory. Pakistan Journal of Commerce and Social Sciences, 9(2),583-597.

Kouser, R., Luqman, R., Yaseen, A., \& Azeem, M.(20I5).Dividend Payout Policy and Financial Crisis: Evidence from the Life Cycle Theory. Pakistan Journal of Commerce and Social Sciences,9(2),583-597.

Kurawa, J.M., \& Ishaku, A.(20I4).The effect of corporate governance on dividend policy of listed banks in Nigeria: A Panel Data Analysis, Research Journal of Finance,2(8),I-I2.

Labhane, N.B. \& Mahakud, J.(2016).Determinants of dividend policy of Indian companies: A panel data analysis, Paradigm,20(I),36-55.

Maladjian, C.\& El Khoury, R.(20I4).Determinants of the dividend policy: an empirical study on the Lebanese listed banks. International Journal of Economics and Finance, 6(4),240-256.

Masum, A.(20I4).Dividend policy and its impact on stock price-a study on commercial banks listed in Dhaka stock exchange, Global Disclosure of Economics and Business, 3(I).

Mbuvi, J. N.(2015).Effect of dividend policy on value creation for shareholders of companies listed in the Nairobi securities exchange. Journal of Economics and Finance,(6)2,35-4I.

Okafor, C.A., \& Mgbame C.O.(20I I).'Dividend policy and share price volatility in Nigeria, Journal of Industrial, Financial \& Business Management,9(I),234-24I.

Pandey, N.S., \& Ashvini, N.(20I6).A study on determinants of dividend policy: empirical evidence from FMCG sector in India. Pacific Business Review International Journal, I(I),I35-I4I.

Sakinc, I. and Gungor, S.(2015).The relationship between ownership structure and dividend: an application in Istanbul stock exchange. Journal of Economics and Development Studies,3(4),19-30.

Thirumagal, P.G. and Vasantha, S.(2018).A research paper on impact of dividend payout on shareholders wealth in Indian industries, International Journal of Pure and Applied Mathematics, I I8(5).

Yegon, C., Cheruiyot, J. \& Sang, J.(20I4).Effects of dividend policy on firm's financial performance: econometric analysis of listed manufacturing firms in Kenya.

Yusof Y., Ismail S.(2016).Determinants of dividend policy of public listed companies in Malaysia. Review of International Business and Strategy,26(I),88-99. http://dx.doi.org/I0.I 108/RIBS-02-20I4-0030
Abbreviations
- Earnings per Share: EPS;
- Price Earnings Ratio: PER;
- Return on Assets: ROA;
- Return on Equity: ROE.

\section{Copyrights}

Copyright for this article is retained by the author(s), with first publication rights granted to the journal. This is an open-access article distributed under the terms and conditions of the Creative Commons Attribution license (http://creativecommons.org/licenses/by/4.0/). 